\title{
Reduction of turbidity and metal pollution from domestic wastewater (greywater) using sediment microbial fuel cell (SMFC)
}

\author{
Sri Magfirah HS ${ }^{*}$, Nursiah La Nafie², Baharuddin³, Budimawan4, Paulina Taba ${ }^{5}$, Eymal B. Demmallino ${ }^{6}$
}

${ }^{1}$ Hasanuddin University, Student of Department of Management Environment, Graduate Studies Program, Makassar, Indonesia.

${ }^{2}$ Hasanuddin University, Department of Chemistry, Faculty of Mathematic and Natural Science, Makassar, Indonesia.

${ }^{3}$ Hasanuddin University, Centre of Biotechnology, Makassar, Indonesia.

${ }^{4}$ Hasanuddin University, Department of Fisheries Biology, Faculty of Marine Science and Fisheries, Makassar, Indonesia.

${ }^{5}$ Hasanuddin University, Department of Chemistry, Faculty of Mathematic and Natural Science, Makassar, Indonesia.

${ }^{6}$ Hasanuddin University, Head of Department of Management Environment, Graduate Studies Program, Makassar, Indonesia.

Correspondence Author: Sri Magfirah HS. Hasanuddin University, Student of Department of Management Environment, Graduate Studies Program, 90245, Makassar, Indonesia.

E-mail: magfirahsri@@gmail.com

Received date: 10 December 2019, Accepted date: 22 January 2020, Online date: 31 January 2020

Copyright: (C) 2020 Sri Magfirah HS et al., This is an open-access article distributed under the terms of the Creative Commons Attribution License, which permits unrestricted use, distribution, and reproduction in any medium, provided the original author and source are credited.

\begin{abstract}
SMFC was a sustainable solution that could currently be applied to address the problem of water availability and environmental pollution with the additional result of electricity. This researched study on discussing the potential of sediment microbial fuel cells (SMFC) in domestic wastewater treatment (greywater) by analyzing the removal efficiency of turbidity and its metals, as well as the electrical energy produced. The studied was conducted by laboratory-scale experiments without any combination of treatments. Two main ingredients, namely domestic wastewater (greywater) and sediment. The sample of domestic wastewater (greywater) was determined at the scale of the settlement area, especially on Old Bitoa Street, Borong, Manggala district, Makassar, and sediment samples were determined from Tallo river sediments, Makassar. The experimental studied in this study carried out by designing an SMFC device made from a polyvinyl chloride (PVC) cylinder, using carbon electrodes with a surface area of $15.5744 \mathrm{~cm}^{2}$, the anode placed in the sediment zone, and the cathode placed in the domestic wastewater zone (greywater). The SMFC was operated in open circuit voltage mode and then monitored for 240 hours under ambient temperature conditions $\left(25^{\circ} \mathrm{C}-30^{\circ} \mathrm{C}\right)$. The quality of domestic wastewater (greywater) was analyzed using turbidity parameters and metal parameters (Fe and Mn metals) according to the Indonesian national standard method (SNI) and showed a significant efficiency of contaminant removal at $88.05 \%$ for turbidity, $\mathbf{6 9 . 1 0 \%}$ for Fe metal, and 56. $63 \%$ for Mn metal. While the performance of SMFC in producing electrical energy observed from the value of the power density produces for $\mathbf{2 4 0}$ haours, the highest power density value was $0.0318 \mathrm{~W} \mathrm{~m}^{-2}$.
\end{abstract}

Keywords: Sediment Microbial Fuel Cell, Bioelectricity, Greywater.

\section{INTRODUCTION}

The decline of clean water supply and the increasing water demand in urban centers have led to increased interest in the reuse of wastewater. In 2015, the global community approved seventeen Sustainable Development Goals (SDGs) that included goals related to access to clean water, sanitation, and hygiene to prevent at least $9.1 \%$ of the burden of disease or $6.3 \%$ of total deaths. These specific targets, such as providing adequate and equitable access to sanitation for everyone, improving water quality by reducing pollution, halving the proportion of untreated wastewater, and increasing global recycling and reuse[1,2].

Reusing greywater is one of the solutions that can currently help the development of sustainable sanitation and ecological sanitation [3]. Greywater is part of domestic wastewater that does not flow through toilets, for example, water from showers, bathtubs, and hand washing basins. Greywater has excellent potential as an alternative water source for purposes such as irrigation, flushing toilets, washing cars, watering the yard, and recharge aquifers. This potential based on the fact that greywater has the highest volume with an average personal use of around 273 liters per day, in addition to having the lowest concentration 
of pollutants, so that it can be the most viable source for reuse. Treatment can save water about $35 \%$ from housing and $15 \%$ from urban water demand $[4,5]$

The reuse of greywater without going through the processing process has an impact on health, especially the risk of exposure (from direct or indirect contact) of low-quality greywater [6]. So that the processing must be done physically, chemically, or biologically. Physical processing is usually carried out by filtration and sedimentation methods. In contrast, chemical processing involves the addition of chemicals or the destruction of contaminants.

The new processing technology currently being developed is Sediment Microbial Fuel Cell (SMFC). Three types of physical, chemical, and biological processing include sedimentation and bioelectrochemical processes. In the bioelectrochemical process, the organic matter contained in wastewater and sediments is converted by microbes into electrical energy [7]. The microorganisms that play a role in it are mostly reducing bacteria such as Geobacter sulfurreducens, Aeromonas hydrophila [8], Geobacter metallireduncens [9], Shewanella putrefaciens [10], Clostridium butyricum [11], and Rhodoferax ferrireduncens [12]. This system has widely developed because it is cost-effective, can work in a variety of environmental conditions, including low operating temperatures, lack of maintenance requirements (e.g., periodic replacements), simple construction, easily placed in remote locations, and no emissions of toxic components [13]. Therefore, the purpose of this research is to create a researchbased Sediment Microbial Fuel Cell (SMFC) system for domestic wastewater treatment (greywater), especially in reducing turbidity and metal pollution.

\section{METHODOLOGY}

\section{A. Materials}

The materials used in this research were domestic wastewater (greywater), sediments, wax glue, graphite electrodes, $1 \mathrm{~m} \mathrm{HCl,} 1$ $\mathrm{m} \mathrm{NaOH}$, digestion solution, sulfuric acid reagent solution, ultrapure water, Whatman no. 41 paper, and distilled water.

\section{B. Sample collection}

The sample of domestic wastewater (greywater) determined at the scale of the residential area, especially on Old Bitoa Street, Borong, Manggala District, Makassar, which was one of the areas in Makassar city that had a sewerage collection channel making it easier for researchers to collect samples. In contrast, sediment samples determined from Tallo river sediments that were overgrown with mangroves, to reduce the accumulation of contaminants in the sediment, so that sediments entered in the SMFC system did not affect the quality of domestic wastewater (greywater) above.

\section{Fabrication and operation of SMFC}

The SMFC was made using a polyvinyl chloride (PVC) cylinder [6] which had a height of $150 \mathrm{~cm}$ and an internal diameter of $11.4 \mathrm{~cm}$. The electrodes used were carbon electrodes with a surface area of $15.5744 \mathrm{~cm}^{2}$ as the cathode and anode. The cathode was positioned in the water zone which maintained up to $90 \mathrm{~cm}$ using domestic wastewater (greywater), while the anode positioned in the sediment zone which had a total height of $50 \mathrm{~cm}$. The SMFC had one sample collection port placed at $10 \mathrm{~cm}$ above the surface of the sediment zone (Figure 1). The SMFC was operated in opened circuit voltage mode (OCV) and monitored for 240 hours under ambient temperature conditions $\left(25^{\circ} \mathrm{C}-30^{\circ} \mathrm{C}\right)$.

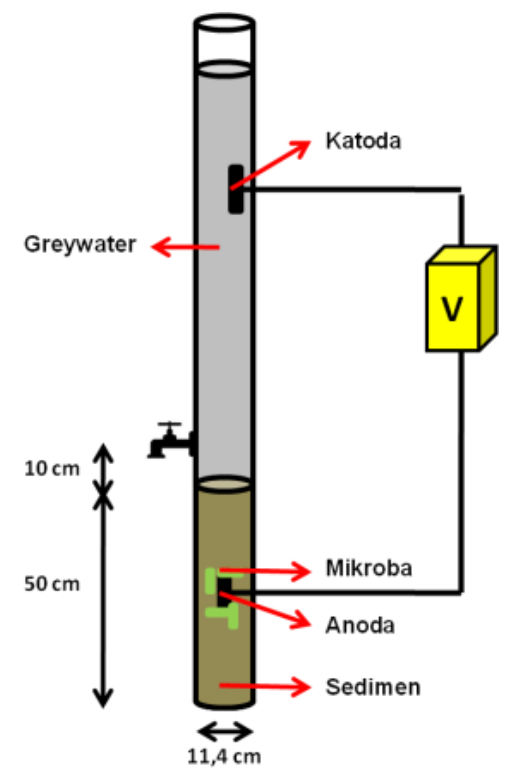

Fig. 1: Schematic diagram of SMFC-1

\section{Analytical measurements and calculations}


The quality of domestic wastewater (greywater) was analyzed using turbidity parameters and metal parameters (Fe and Mn metals) according to the Indonesian national standard method (SNI). While the performance of SMFC in producing bioelectricity could saw from the current strength (I) and voltage (V) generated through measurements using a digital multimeter, using the data of current and voltage could be obtained value of power density $\left(\mathrm{W} \mathrm{m}^{-2}\right)$, which was power per unit area electrode surface. Power density calculated using the following equation:

$$
\text { Power density }\left(\mathrm{W} \mathrm{m} \mathrm{m}^{-2}\right)=\frac{\mathrm{I}(\mathrm{mA}) \times \mathrm{V}(\mathrm{mV})}{\mathrm{A}\left(\mathrm{cm}^{2}\right)} \times 0,1
$$

Where $I$ is the strong current $(\mathrm{mA}), V$ is the voltage $(\mathrm{mV})$, and $A$ is the electrode surface area $\left(\mathrm{cm}^{2}\right)$.

\section{RESULTS AND DISCUSSION}

The quality of domestic wastewater could vary according to local conditions of the region, time of activity (hours, days, seasons), typed of distribution, habits, culture, and lifestyle of the community. Wastewater with high contaminants will cau se pollution and reduce the quality of water bodies. The quality of domestic wastewater (greywater) produced by the community on Old Bitoa Street, Borong, Manggala District, Makassar, before being remediated by the SMFC could be described based on the water quality parameters listed in table 1 :

Table 1: Greywater initial conditions before processing

\begin{tabular}{|c|c|c|}
\hline Parameters & Water quality value & Unit \\
\hline Turbidity & 128 & $\mathrm{NTU}$ \\
\hline Fe metals & 0,0547 & $\mathrm{mg} / \mathrm{L}$ \\
\hline Mn metals & 0,0392 & $\mathrm{mg} / \mathrm{L}$ \\
\hline
\end{tabular}

Initial quality testing of wastewater was very important to understand the characteristics of wastewater to be treated. Wastewater treatment could be done in 3 forms, namely physical treatment such as filtration and sedimentation methods, chemical treatment such as the addition of chemicals or destruction of contaminants, or biological treatment that involves the activity of microorganisms.

In this study, the domestic wastewater treatment method (greywater) used was the SMFC (sediment microbial fuel cell) method. Three types of processing, including physical, chemical and biological processing were included, where for physical processing it was meant that there was a sedimentation process, and for chemical and biological processing incorporated in the bioelectrochemical system.

Sediments were considered to be a place where pollutants accumulate to concentrations that were many times the layer of water at the top. This causes the organic matter contained in the sediment to increase (ranging from 0.4 to 2.2 wt $\%$ ), so that it could be used as a substrate by microorganisms to carry out its activities [13,14].

The microorganisms that played a role were fermentative bacteria and electrogenic bacteria found to coexist in sediments. The most dominant genus was the genus pseudomonas $(10,06 \%)$ and Geobacter $(9,11 \%)$. Fermentative bacteria reform the organic matter in the sediment into simple small molecules. Furthermore, the results of the overhaul could be completely oxidized by electrogenic bacteria [15].

This oxidation process takes place in anaerobic conditions (without oxygen) so it requires electron acceptors other than oxygen such as sulfate and nitrate. However, these electron acceptors continued to decrease and result in the possibility of no degradation at all [16]. To make the degradation process continued, carbon electrodes were given to flow electrons toward areas that had higher electron acceptors such as the wastewater zone. The carbon electrode that releases electrons was the anode (-), while the electrode that receives electrons was the cathode $(+)$.

The oxidation reaction at the anode takes placed spontaneously and continuously releases electrons, so it tends to attract anions and keep cations away. Some oxidation reactions that generally occur naturally could be written as follows:

$\mathrm{C}_{2} \mathrm{H}_{3} \mathrm{O}_{2}^{-}+4 \mathrm{H}_{2} \mathrm{O} \rightarrow 2 \mathrm{HCO}_{3}^{-}+9 \mathrm{H}^{+}+8 \mathrm{e}^{-}$

$\mathrm{C}_{6} \mathrm{H}_{12} \mathrm{O}_{6}+\mathrm{H}_{2} \mathrm{O} \rightarrow 6 \mathrm{CO}_{2}+24 \mathrm{e}^{-}+24 \mathrm{H}^{+}$

$\mathrm{C}_{4} \mathrm{H}_{8} \mathrm{O}_{2}+2 \mathrm{H}_{2} \mathrm{O} \rightarrow 2 \mathrm{C}_{2} \mathrm{H}_{4} \mathrm{O}_{2}+4 \mathrm{H}^{+}+4 \mathrm{e}^{-}$

$\mathrm{C}_{3} \mathrm{H}_{8} \mathrm{O}_{3}+6 \mathrm{H}_{2} \mathrm{O} \rightarrow 3 \mathrm{HCO}_{3}^{-}+17 \mathrm{H}^{+}+14 \mathrm{e}^{-}$

$\mathrm{C}_{4} \mathrm{H}_{5} \mathrm{O}_{5}^{-}+7 \mathrm{H}_{2} \mathrm{O} \rightarrow 4 \mathrm{H}_{2} \mathrm{CO}_{3}+11 \mathrm{H}^{+}+12 \mathrm{e}^{-}$

$\mathrm{C}_{6} \mathrm{H}_{5} \mathrm{O}_{7}{ }^{3-}+11 \mathrm{H}_{2} \mathrm{O} \rightarrow 6 \mathrm{H}_{2} \mathrm{CO}_{3}+15 \mathrm{H}^{+}+18 \mathrm{e}^{-}$

$\mathrm{HS}^{-} \rightarrow \mathrm{S}^{\mathrm{o}}+\mathrm{H}^{+}+2 \mathrm{e}^{-}$etc.

The electrons produced in the reaction above were electrons which will be released by the anode to the cathode. While the protons moved away from the anode and moved towards the cathode through the oxygen gradient naturally. A large number of electron acceptors such as dissolved oxygen in the cathode region causes a reduction reaction. Some reduction reactions that generally occur naturally could be written as follows: 
$\mathrm{O}_{2}+4 \mathrm{e}^{-}+4 \mathrm{H}^{+} \rightarrow 2 \mathrm{H}_{2} \mathrm{O}$

$\mathrm{HCO}_{3}^{-}+9 \mathrm{H}^{+}+8 \mathrm{e}^{-} \rightarrow \mathrm{CH}_{4}+3 \mathrm{H}_{2} \mathrm{O}$

$\mathrm{C}_{2} \mathrm{H}_{3} \mathrm{O}_{2}^{-}+5 \mathrm{H}^{+}+4 \mathrm{e}^{-} \rightarrow \mathrm{C}_{2} \mathrm{H}_{6} \mathrm{O}+\mathrm{H}_{2} \mathrm{O}$

$2 \mathrm{NO}_{3}{ }^{-}+12 \mathrm{H}^{+}+10 \mathrm{e}^{-} \rightarrow \mathrm{N}_{2}+6 \mathrm{H}_{2} \mathrm{O}$

$\mathrm{NO}_{2}^{-}+2 \mathrm{e}^{-}+2 \mathrm{H}^{+} \rightarrow \mathrm{N}_{2}+\mathrm{H}_{2} \mathrm{O}$

$\mathrm{MnO}_{4}^{-}+4 \mathrm{H}^{+}+3 \mathrm{e}^{-} \rightarrow \mathrm{MnO}_{2}+2 \mathrm{H}_{2} \mathrm{O}$

$\mathrm{MnO}_{2}+\mathrm{H}^{+}+\mathrm{e}^{-} \rightarrow \mathrm{MnOOH}_{(\mathrm{s})}$

$\mathrm{Fe}^{3+}+\mathrm{e}^{-} \rightarrow \mathrm{Fe}^{2+}$

$4 \mathrm{Cu}^{2+}+8 \mathrm{e}^{-} \rightarrow 4 \mathrm{Cu}_{(\mathrm{s})}$

$\mathrm{S}_{2} \mathrm{O}_{8}{ }^{2-}+2 \mathrm{e}^{-} \rightarrow 2 \mathrm{SO}_{4}{ }^{2-}$

$\mathrm{Fe}(\mathrm{CN})_{6}{ }^{3-}+\mathrm{e}^{-} \rightarrow \mathrm{Fe}(\mathrm{CN})_{6}{ }^{4-}$ etc.

Half the reactions that occur at each of these electrodes create a potential difference between the two electrodes, causing the formation of electricity and simultaneously the contaminants in wastewater decrease.

\section{A. Greywater Contaminant Removal Efficiency}

The SMFC system was one of the bioremediation techniques that could currently be carried out. Apart from the existence of the conversion of chemical energy into electrical energy, the equipment used was very cheap and easy to did.

The SMFC system was designed based on research with 2 main ingredients namely sediment and wastewater that mimicked the wetland system naturally. Two carbon electrodes were positioned in each zone (the anode in the sediment zone and the cathode in the water zone) with a surface area of $15.5744 \mathrm{~cm}^{2}$.

\section{Turbidity parameters}

The turbidity parameter is a measure of the nature of light transmission from water consisting of suspended material and colloids [17]. The decrease in the number of pollutants in wastewater can see from the level of turbidity, the lower the turbidity level, the lower the level of pollution. Based on research data, the turbidity removal efficiency was 88.05\% (from 128 NTU to 15.3 NTU). It causes by the process of sedimentation or deposition of gravity from water that occurs naturally. Besides, in the process, the contaminants that cause turbidity also decrease along with increasing levels of degradation of organic matter by microbes in sediments.

\section{Fe metals}

Iron (Fe) is one of the most abundant minerals in the earth's crust. The iron dissolved in water depends on the amount of oxygen contained therein and the acidity of the water. Excessive iron in water changes the color of the water to reddish-brown. Otherwise, it will stain the clothes when washed, as well as a disturbing odor [18]. In this study, treatment was carried out in domestic wastewater (greywater) to reduce the concentration of dissolved Fe metal. Based on the data generated, a decrease in the concentration of Fe metals, with a removal efficiency of $69.10 \%$ (from $0.0547 \mathrm{mg} \mathrm{L}^{-1}$ to $0.0169 \mathrm{mg} \mathrm{L}^{-1}$ ).

\section{Mn metals}

Manganese (Mn) is a natural element found in rocks, soil, and water, which consists of about $0.1 \%$ of the earth's crust. Manganese compounds dissolve quickly in water in two primary forms, namely Mn (II) and Mn (IV). Manganese in water can be significantly concentrated biologically by aquatic biota at lower trophic levels [19]. Based on the data generated, there was a decrease in the concentration of Mn metal, with a removal efficiency of $56.63 \%$ (from $0.0392 \mathrm{mg} \mathrm{L}^{-1}$ to $0.017 \mathrm{mg} \mathrm{L}^{-1}$ ).

The results of this greywater treatment expected to be an alternative water source for reuse, such as sanitation hygiene requirements that are following the quality standard according to the Ministerial Regulation Healthy RI No.32 of 2017 . Based on several parameters that have tested for turbidity parameters and metal parameters (Fe metals, and Mn) shows the value that has met the quality standard as presented in Table 2.

Table 2: Comparison of SMFC Processing Results with Quality Standards According to Ministerial Regulation Healthy RI No. 32 of 2017

\begin{tabular}{|c|c|c|c|}
\hline Parameters & Quality of Treated Water & Unit & Water Quality Standards \\
\hline Turbidity & 15,3 & NTU & 25 \\
\hline Fe metals & 0,0169 & $\mathrm{mg} / \mathrm{L}$ & 1 \\
\hline Mn metals & 0,0017 & $\mathrm{mg} / \mathrm{L}$ & 0,5 \\
\hline
\end{tabular}

\section{B. Power generation}

Electricity production by bacteria first carried out using exogenous chemical mediators (natural red, methyl viologen, potassium ferry ride, thonin, anthraquinone 2-6, disulfonate, etc.) for electron transfer from bacteria to electrodes. However, these exogenous chemical mediators (electron transport) are often toxic and unstable. The first breakthrough in the MFC field was when they discovered that without the addition of exogenous mediators, bacteria could transfer electrons to electrodes [15,20]. The performance of SMFC in producing electrical energy observed from the value of power density generated for 240 hours, as shown in Figure 2. Based on the data generated, at the beginning of the operation, the value of power density increased very 
sharply by 0,$0007 ; 0.0065 ; 0.0150 ; 0.0203 ; 0.0229 ; 0.0272 ; 0.0318 \mathrm{~W} \mathrm{~m}^{-2}$ respectively at the $2 \mathrm{nd}, 20 \mathrm{th}, 40 \mathrm{th}, 60 \mathrm{th}, 80 \mathrm{th}, 100 \mathrm{th}$ and 120th hours. However, suddenly at the 140th hour, the value of the power density decreased dramatically until the end of processing from $0.0318 \mathrm{~W} \mathrm{~m}^{-2}$, respectively to $0.0260 ; 0.0246 ; 0.0194 ; 0.0090 ; 0.0030 ; 0 \mathrm{~W} \mathrm{~m}^{-2}$ at the 140 th, 160 th, 180 th, 200th, 220th, and 240th hours.

This decrease in electricity production is likely to be influenced by the amount of oxygen entering the SMFC system, where this system is an electrochemical-based technology, which in the process of oxidation-reduction reactions involves the presence of oxygen as an oxidizing agent at the cathode. The SMFC that designed in this study only relies on the natural oxygen that surrounds it, so that the incoming oxygen is relatively unstable, and depends on the situation and conditions at the time. Without oxygen, oxidation reactions at the cathode will not take place. While the SMFC system is a bioelectrochemical system that involves an oxidation-reduction process, without which if the reaction is interrupted, the desired product will also not achieved.

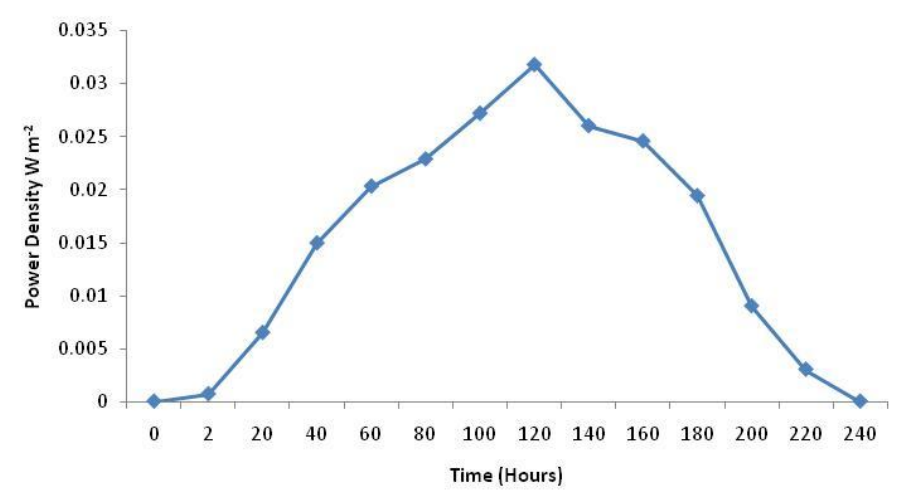

Fig. 8: Power density produced by SMFC

\section{CONCLUSIONS}

Greywater had excellent potential as an alternative water source to meet water availability. However, the reuse of greywater without going processing had an impact on health, so the right treatment was needed, such as SMFC. This system was a bioelectrochemical system that could bioremediate wastewater with additional results in the form of electrical energy. In this study, the quality before and after domestic wastewater (greywater) was analyzed and showed a high contaminant removal efficiency of $88.05 \%$ for turbidity, $69.10 \%$ for Fe metal, and $56.63 \%$ for Mn metal. While the performance of SMFC in producing electrical energy observed from the value of the power density produced for 240 hours, the highest power density value was $0.0318 \mathrm{~W} \mathrm{~m}^{-2}$.

\section{ACKNOWLEDGEMENTS}

We are deeply grateful to Local Society in Old Bitoa Street, Borong, Manggala District, Makassar, who had been willing to provide space for researchers to more easily took samples of domestic wastewater (greywater). This work was supported by Hasanuddin University for the laboratory facilities especially the Analytical Laboratory of the Faculty of Mathematics and Natural Sciences, Makassar, Indonesia.

\section{REFERENCES}

[1] Orner, K.D., and Mihelcic, J.R. A review of sanitation technologies to achieve multiple sustainable development goals that promote resource recovery. Environmental Science: Water Research and Technology. 2018, 4(1), 16-32. DOI: 10.1039/C7EW00195A.

[2] Prüss-Üstün, A., Bos, R., Gore, F., and Bartram, J. 2008. Safer Water Better Health: Costs, Benefits and Sustainability of Interventions to Protect and Promote Health. Geneva: World Health Organization.

[3] Rosemarin A, Ekane N, Caldwell I, Kvarnström E, McConville J, Ruben C and Fogde M 2008 Pathways for Sustainable Sanitation Achieving the Millennium Development Goals. UK: Cambridge University Press.

[4] Thompson, K.A., Summers, R.S., and Cook, S.M. Development and Experimental Validation of The Composition and Treatability of A New Synthetic Bathroom Greywater (SynGrey). Environmental Science: Water Research and Technology. 2017, 3(6), 1120-1131. DOI:10.1039/C7EW00304H

[5] Rana, K., Shah, M., Upadhyay, A. Integrated Approach Towards Greywater Management. International Journal of Engineering Sciences and Research Technology. 2014, 3(1), 239-242.

[6] Bhande, R., Noori, M.T., and Ghangrekar, M.M. Performance Improvement of Sediment Microbial Fuel Cell by Enriching The Sediment with Cellulose: Kinetics of Cellulose Degradation. Environmental Science: Water Research and Technology. 2019, 13 189-196. DOI: 10.1016/j.eti.2018.11.003.

[7] Hamdy, A. Irrigation with Treated Municipal Wastewater. Medit. 1992, 3(1), 50-54. 
[8] Pham, C.A., Jung, S.J., Phung, N.T., Lee, J., Chang, I.S., Kim, B.H., Yi, H., and Chun, J. A novel electrocemically active and Fe (III)-reducing bacterium phylogenetically related to Aeromonas hydrophila isolated from microbioal fuel cell. Anaerobe. 2003, 223, 129-134.

[9] Bond, D.R., and Lovley, D.R. Electricity production by Geobacter sulfurreducens atteched to electrodes. Applied and Environmental Microbiology. 2003, 69(3), 1548-1555. DOI: 10.1128/AEM.69.3.1548-1555.2003.

[10] Kim, H.J., Park, H.S., Hyun, M.S., Chang, I.S., Kim, M., and Kim, B.H.A. Mediator-less microbial fuel cell using a metal reducing bacterium Shewanella putrefacians. Enzyme and Microbial Technology. 2002, 30(2), 145-152. DOI: 10.1016/S0141-0229(01)00478-1.

[11]Park, H.S., Kim, B.H., Kim, H.S., Kim, H.J., Kim, G.T., Kim, M., Chang, I.S., Park, Y.K., and Chang, H.I. A Novel electrocemically active and Fe (III)-reducing bacterium phylogenetically related to Clostridium butyricum isolated from microbioal fuel cell. Anaerobe. 2001, 7(6) 297-306. DOI: 10.1006/anae.2001.0399.

[12] Chadhuri, S.K., and Lovley, D.R. Electricity generation by direct oxidation of glucose in mediatorless microbial fuel cell. Nature Biotechnology. 2003, 21, 1229-1232. DOI: 10.1038/nbt867.

[13]Zabihallahpoor, A., Rahimnejad, M., and Talebnia, F. Sediment microbial fuel cells as a new source of renewable and sustainable energy: present status and future prospects. RSC Advances. 2015, 5(114), 94171-94183. DOI: 10.1039/C5RA15279H.

[14] Abbas, S.Z., Mohdrafatullah, Ismail, N., and Izzuddinsyakir, M. Outlook of Sediment Microbial Fuel Cell For Power Generation and Bioremediation of Contaminants. International Journal of Advances in Science Engineering and Technology. 2017, 5(3), 45-47.

[15] Wu, M. S., Xu, X., Zhao, Q., and Wang, Z. Y. Simultaneous removal of heavy metals and biodegradation of organic matter with sediment microbial fuel cells. RSC Advances. 2017, 7(84), 53433-53438. DOI: 10.1039/C7RA11103G.

[16] Xu, B., Ge, Z., and He, Z. Sediment Microbial Fuel Cells for Wastewater Treatment: Challenges and Opportunities. Environmental Science: Water Research and Technology. 2015, 1(3), 279-284. DOI: 10.1039C5EW00020C.

[17]Zlatunova, D., VICAIRE (Virtual Campus In Hydrology and Water Resources Management) Module 2, Part 2, (online), 2005, (https://echo2.epfl.ch/VICAIRE/mod_2/chapt_2/main.htm, accessed 12 November 2019).

[18] Pescod, M.B. 1992. Wastewater Treatment and Use in Agriculture. FAO: Rome.

[19] Howe, P.D., Malcolm, H.M., and Dobson, S. 2005 Manganese and Its Compounds: Environmental Aspects. WHO: Switzerland.

[20] Nwadinigwe, C.A., Udo, G.J., and Nwadinigwe, A.O. Seasonal variations of heavy metals concentrations in sediment samples around mayor tributaries in ibeno coastal area, Niger Delta, Nigeria. International Journal of Scientific and Technology Research. 2014, 3(11): 254-265. 